\title{
Endocrine profiles and kidney function markers of apparently healthy pregnant and lactating Duroc sows
}

\author{
Nweze, E.C \\ Department of Veterinary Physiology and Pharmacology, College of Veterinary Medicine, Michael Okpara University of \\ Agriculture, Umudike, Abia State, Nigeria \\ *Corresponding author: ernest.nweze@yahoo.com; Tel: +2348066336466
}

\begin{abstract}
This experiment was carried out to evaluate the effects of reproductive activities (pregnancy and lactation) on certain serum endocrine profiles and kidney function markers of Duroc sows. Thirty (30) sexually matured cycling apparently healthy Duroc sows and eight (8) Duroc boars (38 pigs), of mean weight $55.36 \pm 0.48 \mathrm{~kg}$, aged between13and 15 months were used for this study. The sows (30) were randomly assigned to five groups (A to E) of six sows per group in a completely randomized design (CRD). Group A: Non pregnant (control), Group B: Early gestation (38 days), Group C: Mid gestation (78 days), Group D: Late gestation (110 days) and Group E: Post gestation (7 days postpartum). The mean serum progesterone $\left(\mathrm{P}_{4}\right)$ concentration of group D sows was significantly $(\mathrm{p}<0.05)$ increased when compared to group E. The mean serum thyroxine $\left(\mathrm{T}_{4}\right)$ concentration of group D sows (3rd trimester) was significantly $(\mathrm{p}<0.05)$ increased when compared to groups $\mathrm{C}$ and $\mathrm{E}$. The mean blood urea nitrogen (BUN) concentration of the treated group $(C)$ was significantly $(p<0.05)$ higher when compared to group B. The mean creatinine concentration of group D was significantly $(\mathrm{p}<0.05)$ higher when compared to groups E, B and the control. The mean BUN/CRT ratio of group B sows was significantly $(\mathrm{p}<0.05)$ higher when compared to groups $\mathrm{C}, \mathrm{D}, \mathrm{E}$ and the control. There were however, no significant variations $(p>0.05)$ in the mean oestradiol $\left(E_{2}\right)$, cortisol $(C)$, creatinine (CRT) concentrations and BUN/CRT ratio among all the groups. In conclusion, the serum endocrine and kidney function markers of Duroc sows in this study were significantly influenced by gestation. This study has established reference values of the endocrine profiles and kidney function markers of Duroc sows during gestation that are consistent with normal health.
\end{abstract}

Keywords: Duroc pigs, endocrine profiles, gestation, kidney function

\section{INTRODUCTION}

Pig production remains one of the veritable sources of supply of animal protein (Apata \& Ojo, 2000; Udofia et al., 2007). Reproduction of pigs provides man with a more uniform supply of pork meat (Chandy, 2004; Ayalew et al., 2011) and by-products such as pigskin and bristle used in the manufacture of light leather and brushes especially in Asian countries (Young, 2005). The pig's output; yield of meat/tonne of live weight of breeding pigs especially number of sows per year is about six times that of cattle (Mpofu \& Makuza, 2003). Pig husbandry in Nigeria thrive well under a wide range of ecological conditions (Balogun \& Olumeyan, 1988), however productivity of breeding stock is highly dependent on its growth rate and reproductive efficiency (Adebambo, 1981, 1983).
Major adaptations in maternal physiology and metabolism are required for successful pregnancy outcome. Blood serum biochemical profile testing is a pre-symptomatic diagnostic tool to assess the swine herd's nutritional status and other productive and reproductive disorders (Pathan et al., 2011).The profile may vary according to factors such as origin, climate, management practices, geographical distribution, season and reproductive stage of animals (Cozzi et al., 2011; Pal \& Acharya, 2013; Mahima et al., 2013). Physiological changes in pregnancy are primarily due to the changes in the hormonal milieu (Chandra et al., 2012). Pacheco et al. (2016) and Souza et al. (2018) emphasized thatphysiological changes are related to nutrient expenditure with foetal growth, placental functioning, increased foetal covering and fluid, uterine wall and mammary glands to 
highlight the increase in the metabolic rate that occurs during gestation.

Once mating and fertilization are successfully completed, the trophoblast signals its presence to the maternal system to prevent luteolysis and maintain progesterone production, which is essential for the establishment of pregnancy (Geisert \& Malayer, 2000).The implantation event is accompanied by significant changes in the tissue concentration of various cytokines, adhesion molecules, hormones, enzymes and growth factors, all of which may be crucial in initiating the foeto-maternal relationship (Rice \& Chard, 1998; Saito, 2000).Progesterone acts to prevent the resumption of cyclicity, prepares the uterus for implantation and maintains myometrial quiescence (Geisert \& Malayer, 2000). Progesterone is also believed to aid in the maintenance of uterine immune system during pregnancy (Rahman, 2002). Actually, myometrial quiescence during pregnancy is achieved by the combined action of progesterone, relaxin, prostacyclin and nitric oxide (Geisert $\&$ Malayer, 2000). Together with estrogen, progesterone acts to transform the endometrium into a secretory tissue capable of supporting both the pre- and post-implantation conceptus.Heshmat et al. (1984) reported that plasma triiodothyronine and thyroxine concentrations in the dromedary camel increased throughout pregnancy. Currently, there are no data available on the serum endocrine profiles and kidney function markers that occur during the transition period in Duroc sows kept in Nigeria. Therefore, the aim of this study was to determine the effect of pregnancy and lactation on certain serum endocrine profiles and kidney function markers of Duroc sows.

\section{MATERIALS AND METHODS}

\section{EXPERIMENTAL ANIMALS}

This experiment was carried out on Duroc pigs obtained from Chidiebere commercial breeding farm and kept in Chidiebere commercial breeding farm located at Ndoro in Ikwuano LGA, Abia State, Nigeria. Thirty (30) sexually matured cycling apparently healthy Nigerian Duroc sows and eight (8) Duroc boars (38 pigs), of mean weight 55.36 \pm 0.48 $\mathrm{kg}$, aged between 13 and 15 months were used for this study. The sows and boars were acclimatized for three weeks during which they were dewormed using ivermectin at a dose of $300 \mu \mathrm{g} / \mathrm{kg}$ subcutaneous (SC) ones, for internal parasites and repeated 10-14 days for external parasites. The Duroc pigs were kept in well ventilated pens at room temperature $\left(25-27^{\circ} \mathrm{C}\right)$ and 12 hours light/darkness cycle maintained.

\section{EXPERIMENTAL DESIGN}

Thirty (30) Duroc sows were randomly assigned to five groups (A to E) of six sows per group in a completely randomized design (CRD). Group A: Non pregnant (control), Group B: Early gestation (38 days), Group C: Mid gestation (78 days), Group D: Late gestation (110 days) and Group E: Post gestation ( 7 days post-partum). The sows were synchronized using $\mathrm{PGF}_{2 \alpha}$ given twice, 11 days apart at a dose of $10 \mathrm{mg} / \mathrm{kg}$ intramuscular (IM). A total of eight boars ( 2 boars for each group) were introduced to naturally serve the sows in groups $\mathrm{B}, \mathrm{C}, \mathrm{D}$ (pregnant groups) and $\mathrm{E}$ (lactation group). Following successful mating, pregnancy was confirmed by ultrasonography (Ali \& Fahmy, 2008) between days 22-23 after the introduction of sexually mature boars. The pregnant sows were identified with tag letters thus, $\mathrm{B}_{1-6}, \mathrm{C}_{1-6}, \mathrm{D}_{1-6}$, and kept in separate pens until farrowing and are maintained in these separate pens throughout lactation. The postpartum sows were also kept in separate pens and identified thus; $\mathrm{E}_{1-6}$ while the control sows were identified thus $A_{1-6}$ and kept together in a pen. The sows were fed twice daily while the piglets received breast milk only from their mothers until the end of lactation at 28 days. Sows, boars and piglets were provided with clean fresh water ad libitum throughout the period of the study. Four milliliters $(4 \mathrm{ml})$ of blood was collected from each sow in a group from the femoral vein and dispensed into plane test tubes and allowed to clot in a slanting position for 2 hours and centrifuged at 2,500 RPM for 5minutes. The resulting sera were aspirated, stored at $-20^{\circ} \mathrm{C}$ and used to determine the concentrations of oestradiol, progesterone, cortisol and thyroxine using microplate enzyme immunoassay (EIA) technique (Tietz, 1995), blood urea nitrogen (Burtis \& Ashwood, 1999) and creatinine (Newman \& Price, 1999). Serum BUN/CRT ratio was determined by calculation.

\section{DATA ANALYSIS}

The data collected for each of the serum endocrine profiles and kidney function markers were subjected to One Way Analysis of Variance (ANOVA) using SPSS statistical package (version 21.0). Variations in means were separated using Duncan's New multiple Range Test (Steel \& Torrie, 1980). Probability values $<0.05$ were considered significant.

\section{RESULTS}

The mean serum progesterone $\left(\mathrm{P}_{4}\right)$ concentration of group $\mathrm{D}$ sows was significantly $(\mathrm{p}<0.05)$ increased when compared to group E. The mean serum thyroxine $\left(\mathrm{T}_{4}\right)$ concentration of group D sows (3rd trimester) was significantly $(\mathrm{p}<0.05)$ increased when compared to groups $\mathrm{C}$ and $\mathrm{E}$ but showed no significant $(p>0.05)$ variations when compared to group B and the control. The mean blood urea nitrogen (BUN) concentration of the treated group (C) was significantly $(\mathrm{p}<0.05)$ higher when compared to group $\mathrm{B}$. The mean creatinine concentration of group D sows was significantly $(\mathrm{p}<0.05)$ higher when compared to groups $\mathrm{E}, \mathrm{B}$ and the control. The mean BUN/CRT ratio of group B sows was 
significantly $(\mathrm{p}<0.05)$ higher when compared to groups $\mathrm{C}, \mathrm{D}$, $\mathrm{E}$ and the control. There were however, no significant variations $(p>0.05)$ in the mean oestradiol $\left(E_{2}\right)$, cortisol $(C)$, creatinine (CRT) concentrations and mean BUN/CRT ratio among all the groups. serum blood urea nitrogen (BUN) concentration of mid gestation sows compared to the non-mated group agrees with the report of Soliman (2014) in Ossimi sheep. The elevated urea/creatinine ratio is important indicator of the increased glomerular filtration rate (GFR) which increases especially in late gestation due to the increased total blood volume. The higher urea/creatinine ratio in late pregnant sows relative to
Table I: The mean hormonal profiles of Duroc sows at different stages of gestation $\mathrm{E}_{2}=$ Estrogen, $\mathrm{P}_{4}=$ Progesterone, $\mathrm{T}_{4}=$ Thyroxine, $\mathrm{C}=$ Cortisol

\begin{tabular}{llllll}
\hline Parameters & $\begin{array}{l}\text { Pre-gestation } \\
\text { (control) }\end{array}$ & Early gestation & Mid gestation & $\begin{array}{l}\text { Late } \\
\text { gestation }\end{array}$ & $\begin{array}{l}\text { Post-gestation } \\
\text { (lactation) }\end{array}$ \\
\hline $\mathrm{E}_{2}(\mathrm{pg} / \mathrm{ml})$ & $202.93 \pm 25.88$ & $120.69 \pm 37.47$ & $106.11 \pm 37.03$ & $83.43 \pm 9.54$ & $251.60 \pm 186.73$ \\
$\mathrm{P}_{4}(\mathrm{ng} / \mathrm{ml})$ & $22.61 \pm 15.25^{\mathrm{ab}}$ & $40.19 \pm 13.82^{\mathrm{ab}}$ & $54.79 \pm 2.64^{\mathrm{b}}$ & $55.62 \pm 8.16^{\mathrm{b}}$ & $7.47 \pm 0.35^{\mathrm{a}}$ \\
$\mathrm{C}(\mu \mathrm{g} / \mathrm{dl})$ & $24.79 \pm 10.33$ & $13.66 \pm 2.09$ & $13.42 \pm 1.99$ & $10.43 \pm 2.50$ & $16.36 \pm 2.41$ \\
$\mathrm{~T}_{4}(\mu \mathrm{g} / \mathrm{dl})$ & $17.27 \pm 0.29^{\mathrm{b}}$ & $14.80 \pm 2.05^{\mathrm{b}}$ & $10.97 \pm 0.07^{\mathrm{a}}$ & $17.50 \pm 0.38^{\mathrm{b}}$ & $11.20 \pm 0.06^{\mathrm{a}}$ \\
\hline
\end{tabular}

${ }^{\mathrm{ab}}$ Mean values in the same row with different superscripts are significantly different $(\mathrm{P}<0.05)$

Table II: The mean kidney function markers of Duroc sows at different stages of gestation

\begin{tabular}{|c|c|c|c|c|c|}
\hline Parameters & $\begin{array}{c}\text { Pre- } \\
\text { gestation } \\
\text { (control) }\end{array}$ & $\begin{array}{l}\text { Early gestation } \\
\text { (Ist trimester) }\end{array}$ & $\begin{array}{c}\text { Mid } \\
\text { gestation }\left(2^{\text {nd }}\right. \\
\text { trimester }) \\
\end{array}$ & $\begin{array}{c}\text { Late } \\
\text { gestation }\left(3^{\text {rd }}\right. \\
\text { trimester }) \\
\end{array}$ & $\begin{array}{c}\text { Post- } \\
\text { gestation } \\
\text { (lactation) }\end{array}$ \\
\hline BUN (mg/dl) & $6.32 \pm 0.06^{6}$ & $5.56 \pm 0.29^{\mathrm{a}}$ & $6.63 \pm 0.31^{b}$ & $6.29 \pm 0.05^{b}$ & $6.30 \pm 0.10^{b}$ \\
\hline CRT (mg/dl) & $2.86 \pm 0.28$ & $2.46 \pm 0.09$ & $2.73 \pm 0.26$ & $2.46 \pm 0.09$ & $2.79 \pm 0.43$ \\
\hline $\begin{array}{l}\text { BUN/CRT } \\
\text { ratio }\end{array}$ & $2.25 \pm 0.21$ & $2.27 \pm 0.17$ & $2.49 \pm 0.33$ & $2.56 \pm 0.08$ & $2.36 \pm 0.34$ \\
\hline
\end{tabular}

${ }^{\mathrm{ab}}$ Mean values in the same row with different superscripts are significantly different $(\mathrm{P}<0.05)$ non-pregnant counterparts could be due to the increase in GFR and reproductive status of the sows (Fischbach, 2000).

\section{CONCLUSION}

The serum endocrine profiles and kidney function markers of Duroc sows in this study were significantly influenced by gestation. The endocrine and kidney function markers of sows used in this study are within the physiological range required for the maintenance of homeostasis and health essential for efficient reproduction. Therefore the sows used in this study during gestation suggest having good blood compositions capable of supporting optimal reproductive performance. This study has established reference values of the endocrine profiles and kidney function markers of Duroc sows during pregnancy and lactation that are consistent with normal health in this species.

\section{ACKNOWLEDGEMENTS}

The author acknowledges the efforts of $\mathrm{Mr}$ Chidiebere (Chidiebere Farms) for providing me with his farm and other logistics used for this study.

\section{REFERENCES}

Adebambo, A.O. (1981). Comparison of the indigenous and exotic pure and crossbreed sows in Southern Nigeria: Relationship of dam and litter performance. Nigeria Journal of Animal Production, 8, 67-74.

Adebambo, A.O. (1983). Comparative growth and carcass performance of progenies sired by purebred Large White and Hampshire boars and their crosses with the Nigerian local breeds. Nigeria Journal of Animal Production, 10, 124-129.

Ali, A. \& Fahmy, S. (2008). Ultrasonographic fetometry and determination of foetal sex in buffaloes (Bubalus bubalis). Animal Reproduction Science, 106, 90-99. 
Antunovic, Z., Senčić, D., Šperada,M. \& Liker, B. (2002). Influence of the season and the reproductive status of ewes on blood parameters. Small Ruminant Research, $45,39-44$.

Apata, D.F. \& Ojo, Y. (2000). Efficacy of the Trichodermaviride enzyme complex in broiler starter fed cowpea. Testa Based Diets. Proceedings of the 25th Annual Conference of Nigerian Society for Animal Production.

Ayalew, W., Danbaro, G., Dom, M., Amben, S., Besari, F., Moran, C. \& Nidup, K. (2011).Genetic and cultural significance of indigenous pigs in Papua New Guinea and their phenotypic characteristics. Animal Genetic Resources, 48, 37-46.

Balogun, T.F. \& Olumeyan, D.B. (1988).The position of swine in Nigeria's livestock industry. Samaru Journal of Education, 2, 8-15.

Baumgartner, W. \& Pernthaner, A. (1994).Influence of age, season, and pregnancy upon blood parameters in Austrian Karakul sheep. Small Ruminant Research, 13, 147-151.

Burtis, C.A. \& Ashwood, E.R. (1999).editors. Tietz Textbook of clinical Chemistry. 3rd ed. Philadelphia: W.B Saunders company; p. 1838.

Carcangiu, V., Vacca, G.M., Mura, M.C., Dettori, M.L., Pazzola, M., Fioro, M. \& Bini, P.P.(2007). Blood parameters during lactation and dry period in sarda sheep breed. In 'XV Congress of Mediterranean Federation for Health and Production of Ruminants', 15-19 May, Kusadasi, Turkey. pp. 109-114.

Chandra, S., Tripathi, A.K., Mishra, S., Amzarul, M. \& Vaish, A.K. (2012). Physiological changes in haematological parameters during pregnancy. Indian Journal of Haematology and Blood Transfusion, 28, 144-146.

Chandy, K.T. (2004). Pig introduction: Breeds and Characteristics. Retrieved March 22, 2013 from http://www.inseda.org/additional material/CDAgriculture and Environment Education/24-Animal Husbandry - Pigs (PGS)/Pig Introduction-190.doc.

Cozzi, G., Ravarotto, L., Gottardo, F., Stefani, A. L., Contiero, B., Moro, L. \& Dalvit, P. (2011). Short communication: Reference values for blood parameters in Holstein dairy cows: Effects of parity, stage of lactation, and season of production. Journal of Dairy Science, (Vol. 94).

Durak, M.H.\& Altinek, A. (2006).Effect of energy deficiency during late pregnancy in Chiosewes on free fatty acids, $\beta$-hydroxybutyrate and urea metabolites.Turkish Journal of Veterinary and Animal Sciences,30, 497-502.

El-Sherif,M.M.A. \& Assad F. (2001).Changes in some blood constituents of Barki ewes duringpregnancy and lactation under semi-arid conditions. Small Ruminant Research, 40, 269-277.

Fischbach, F.A. (2000).Manual of Laboratory and Diagnostic Tests. 6th Edition, Lippincott, Philadelphia, 5-155.
Franczak, A. \& Kotwica, G. (2010). Androgens and estradiol-17 beta production by porcine uterine cells: In vitro study. Theriogenology, 73(2), 232-241.

Geisert, R.D. \& Malayer, J.R. (2000).Implantation.In "Reproduction in Farm Animals" (B. Hafez and E. S. E.Hafez, Eds.), Lippincott Williams \& Wilkins, Philadelphia. pp. 126-139.

Hamadeh, M.E., Bosted, H. \& Failing, K. (1996). Studies on relevant metabolism parameters in blood plasma of highly pregnant and non-pregnant ewes. Berliner und Munchener Tierarztliche Wochenschrift, 109, 81-86.

Heshmat, H.A., Tha, A., Ismail, A.A. \& Sami, M.B.A. (1984). Levels of thyroid hormones in the plasma of pregnant camels (Camelusdromedarius). Indian Journal of Animal Science, 54, 663-665.

Karapehlivan, M., Atakisi, E., Atakisi, O., Yucayurt, R. \& Pancarci, .M. (2007). Blood biochemical parameters during lactation and dry period in Tuj ewes. Small Ruminant Research, 73, 267-271.

Lohle, K.U. (1992). Untersuchungenüber den Gehaltan Harnstoff, Gesamtbilirubin, Gesamtewei $\beta$ und KreatininimBlut plasma Afrikanischer Zwergziegen. Mh. Veterinary Medicine, 47, 487-493.

Mahima, Singh, K. V., Verma, A. K., Kumar, V., Singh, S. K.\& Roy, D. (2013). Haematological and serum biochemical profile of apparently healthy hariana cattle heifers in Northern India. Pakistan Journal of Biological Sciences, 1423-1425.

Mpofu, I. \& Makuza, S.M.M. (2003). Pig production science and technology, 1st ed., Upfront Publishing, UK.

Newman, D.J. \& Price, C.P. (1999). Renal function and nitrogen metabolites. In: Burtis CA, Ashwood ER, editors. Tietz Textbook of Clinical Chemistry. 3rd ed. Philadelphia: W.B Saunders Company; p. 1204-1270.

Pacheco, A., Quirino, C.R., Madella-Oliveira, A.F., Menário, C.W., Rua, M.A.S. \& Vega, W.H.O. (2016). Alteraçõesnos parâmetros hematológico durante a gestação e no pós-parto de cabras da raçaSaanencriadas no sul do Espírito Santo. Pesquisa Veterinária Brasileira, 36, 15-20.

Pal, P. \& Acharya, H. R. (2013). Subclinical metabolic disorders in post-partum cross bred HF cattle. International Journal of Pharma Medicine and Biological Sciences, 2(2), 57-62.

Pathan, M. M., Das, H., Md. J.Z, Siddiquee, G.M., Latif, A., Parsani, H.R. \& Sastry, G.A. (2011). Comparative studies on haemato-biochemical profile of cyclic and non-cyclic Holstein Friesian cross-bred cows. Wayamba Journal of Animal Science, pp.69-70.

Rahman, A.N.M.A. (2002). "Changes in the Uterine Immune System during Pregnancy in Sheep".Unpublished (MVSc Thesis), Department of Veterinary Science, the University of Melbourne, Melbourne, Australia. pp.1140.

Rice, A. \& Chard, T. (1998). Cytokines in implantation Cytokine Growth Factor Review, 9, 287-296.

Saito, S. (2000). Cytokine network at the feto-maternal interface. Journal of Reproduction and Immunology, 47, 87-103. 
Salem, N.Y. (2017). Effect of lactation on haematobiochemical and minerals constituents in small ruminant. International Journal of Veterinary Science, 6(1), 53-56.

Sheldrick, E.L., Ricketts, A.P. \& Flint, A.P.F. (1981).Placental production of $5 \beta$-pregnane-3 $\alpha, 20 \alpha-$ diol in goats. Journal of Endocrinology, 90, 151-158.

Soliman, E.B. (2014). Effect of Physiological status on some Hematological and Biochemical Parameters of Ossimi sheep. Egyptian Journal of Sheep and Goat Sciences, 9(2), 33- 42.

Souza, L.M., Mendonça, C.L., Assis, R.N., Nunes, D., Oliveira Filho, E.F., Souto, R.J.C., Soares, P.C. \& Afonso, J.A.B. (2018). Use of troponin I and CK-MB as heart biomarkers in sheep affected by pregnancy toxemia.Medicina Veterinária (UFRPE), 12, 143.
Udofia, E.H., Solomon, I.P., Obasi, O.L. \& Okonkwo, A.C. (2007). Performance of broiler birds as influenced by herbal nutritive supplement (Stressroak). Proceedings of the 41st Annual Conference of the Agriculture Society of Nigeria, pp. 313.

Young, M. (2005). Efficiency of pork production: a USA, Canada and Ireland comparison. Allen D. Leman Swine Conference, pp. 124.

Article history: Received: Sept. 13, 2021, Revised: Dec.24, 2021, Accepted: Dec.29, 2021

Steel, R.G.D. \& Torrie, J.H. (1980).Principles and procedures of statistics, Second Edition, New York: McGraw-Hill Book Co.

Tietz, N.W. (1995). (ed.). Clinical guide to laboratory tests, 3rd ed. Philadelphia, WA Saunders Co. 